\title{
Screening for Malignant Hyperpyrexia
}

\author{
F. RICHARD ELLIS, NIALL P. KEANEY, D. G. F. HARRIMAN, D. W. SUMNER, \\ K. KYEI-MENSAH, J. H. TYRRELL, J. B. HARGREAVES, R. K. PARIKH, P. L. MULROONEY
}

British Medical fournal, 1972, 3, 559-561

\section{Summary}

The methods used to screen patients for malignant hyperpyrexia at present are not sufficiently accurate. This paper reports more specific methods of detecting patients liable to develop malignant hyperpyrexia. A motor-point muscle biopsy is performed for histopathological examination and to detect muscle contracture in vitro after exposure to halothane and suxamethonium.

\section{Introduction}

There can be few more catastrophic events in clinical medicine than the sudden development of malignant hyperpyrexia during anaesthesia. Malignant hyperpyrexia is characterized by a progressive and fulminating rise in temperature at a rate of at least $2^{\circ} \mathrm{C} / \mathrm{hr}$ (Keaney and Ellis, 1971), and skeletal muscle contracture and acidosis usually develop. The potentially fatal nature of this condition makes it imperative that anaesthetists should recognize the susceptible patient, and yet its low incidence in the anaesthetized population (variously quoted as between $1: 14,000$ and $1: 75,000$ ) militates against the preoperative screening of all patients with costly or timeconsuming tests.

There are, however, some pointers which help to identify the susceptible patient. Malignant hyperpyrexia is a pharmacogenetic disease with a dominant inheritance, and the history of an anaesthetic death with hyperpyrexia places other members of the family under suspicion. A close association with myopathy has been noted (Denborough et al., 1962; Steers et al., 1970; Ellis et al., 1971), and patients with either myopathy or related conditions such as hernia, strabismus, and orthopaedic abnormalities must be considered to be at greater risk than the general population.

The value of increased serum creatine phosphokinase (SCPK) activity in detecting susceptible subjects in the general population (Isaacs and Barlow, 1970) is limited because SCPK activity is increased after exercise (Griffiths, 1966) and in certain diseases which are not related to malignant hyperpyrexia. Thus if the SCPK level alone is used to detect susceptible patients many false positive results will be obtained. It is this lack of specificity (commented on by Larard et al., 1972) which led us to devise more-specific methods for de-

University of Leeds

F. RICHARD ELLIS, PH.D., F.F.A.R.C.S., Senior Lecturer in Anaesthesia NIALI P. KEANEY, M.B., B.CH., Research Assistant

D. G. F. HARRIMAN, M.D., F.R.C.P., Senior Lecturer, Department of Neuropathology
Ne F. HARRIM

Leeds (St. James's) University Hospital

D. W. SUMNER, M.B., M.R.C.P., Consultant Neurologist

Pontefract General Hospital

K. KYEI-MENSAH, M.B., M.R.C.P., Consultant Anaesthetist

J. H. TYRRELL, M.B., F.F.A.R.C.S.I., Consultant Anaesthetist

Walton Hospital, Liverpool

J. B. HARGREAVES, M.R.C.S., L.R.C.P., F.P.A.R.C.S., Consultant Anaesthetist

Western Infirmary, Glasgow

R. K. PARIKH, M.B., F.F.A.R.C.S., Senior Registrar in Anaesthetics

Mansfield General Hospital

P. L. MULROONEY, M.B., F.F.A.R.C.S., Consultant Anaesthetist tecting susceptibility to malignant hyperpyrexia in relatives of patients who have developed the condition.

We report here the investigation of seven subjects from four different families in each of which there had been a case of malignant hyperpyrexia. The investigations included neurological history and examination, determination of resting SCPK activity and serum aldolase and electrolyte levels, and motor-point muscle biopsy. Muscle specimens were examined by routine and histochemical methods and by electron microscopy, and living muscle specimens were investigated pharmacologically in vitro to detect muscle contracture in the presence of two of the commonly associated "triggering" drugs used during anaesthesia-namely, halothane and suxamethonium (Ellis et al., 1971).

\section{Methods}

Biopsy was performed on the vastus medialis muscle under local infiltration anaesthesia. The motor point was identified by electrical stimulation of the exposed muscle, and specimens were taken to include the motor innervation. The technique of motor-point muscle biopsy was described in detail by Harriman (1961).

For the neuropharmacological investigations the muscle specimens were kept in fresh Krebs solution gassed with $5 \%$ carbon dioxide in oxygen until used. Each specimen, after microdissection to remove unwanted and damaged tissue, was secured in a tissue bath which was continuously perfused with Krebs solution at $37^{\circ} \mathrm{C}$ and $5 \%$ carbon dioxide in oxygen. The free end of the muscle specimen was attached to a Sangamo D1/0.100 in force-displacement transducer which sensed muscle activity; this was displayed on a Devices M2 recorder. Muscle contracture was indicated by a shift in the baseline of the recorded signal. Muscle twitches produced by electrical stimulation of the muscle via platinum electrodes were recorded for each specimen to prove viability.

Halothane $(1-4 \% \mathrm{v} / \mathrm{v}$ dial setting) vaporized in a Fluotec vaporizer (Cyprane) was administered via the $5 \%$ carbon dioxide/oxygen gas mixture. Suxamethonium $(0.33 \mathrm{mM}$ and $0.66 \mathrm{mM}$ ) was added to the perfusate.

All experiments were conducted at $37^{\circ} \mathrm{C}$, and later a temperature-controlled room was used. Tissue-bath temperature was recorded continuously with a thermistor probe.

\section{Results}

The results are summarized in the Table. The relationship of each subject to the patient who had had malignant hyperpyrexia is shown.

The only biochemical abnormality found was a raised SCPK activity in four subjects; neither serum aldolase nor serum electrolyte levels were significantly or consistently outside normal limits.

None of the subjects complained of symptoms which could be attributed to myopathy, and yet minimal neurological signs consistent with mild myopathy were present in the four subjects who had raised resting SCPK activity.

Neurohistological evidence of myopathy was found in five subjects (see Table). The abnormalities were relatively mild and included undue variation in fibre calibre, fibre atrophy with nuclear clumping, mitochondrial aggregates, and "moth- 
Details of Subjects undergoing Biopsy

\begin{tabular}{|c|c|c|c|c|c|c|c|c|c|c|}
\hline \multirow{2}{*}{\multicolumn{3}{|c|}{$\begin{array}{l}\text { Case No. } \\
\text { of } \\
\text { Subject of } \\
\text { Present } \\
\text { Investigation }\end{array}$}} & \multirow[b]{2}{*}{ Family } & \multirow{2}{*}{$\begin{array}{l}\text { Relationship to } \\
\text { Case of Malignant } \\
\text { Hyperpyrexia }\end{array}$} & \multirow{2}{*}{$\begin{array}{l}\text { Relevant } \\
\text { Neurological } \\
\text { Symptoms }\end{array}$} & \multirow[b]{2}{*}{ Myopathic Signs } & \multirow[b]{2}{*}{ SCPK* } & \multirow{2}{*}{$\begin{array}{l}\text { Histological } \\
\text { Evidence of } \\
\text { Myopathy }\end{array}$} & \multicolumn{2}{|c|}{ Muscle Contracture In Vitro } \\
\hline & & & & & & & & & Halothane Alone & $\begin{array}{c}\text { Halothane } \\
+ \\
\text { Suxamethonium }\end{array}$ \\
\hline 1 & . & -. & \} & Brother (aged 24 years) & Nil & Absent ankle reflexes, unstable & 150 & + & + & + \\
\hline $\begin{array}{l}2 \\
3 \\
4\end{array}$ & $\ddot{0}$ & $\because \ddot{x}$ & $\stackrel{\mathbf{B}}{\mathbf{C}}$ & $\begin{array}{l}\text { Mother (aged } 49 \text { years) } \\
\text { Sister (aged } 52 \text { years) } \\
\text { Propositus (aged } 10 \text { years) }\end{array}$ & $\begin{array}{l}\text { Nil } \\
\text { Nil } \\
\text { Nil }\end{array}$ & $\begin{array}{l}\text { phigh weakness } \\
\text { Absent ankle reflexes } \\
\text { Slight weakness of shoulder }\end{array}$ & $\begin{array}{r}233 \\
79 \\
62\end{array}$ & $\begin{array}{l}+ \\
+ \\
+\end{array}$ & $\frac{ \pm}{+}$ & $\begin{array}{l}+ \\
+ \\
+\end{array}$ \\
\hline $\begin{array}{l}5 \\
6 \\
7\end{array}$ & $\ddot{0}$ & $\ddot{x}$ & $\geqslant D$ & $\begin{array}{l}\text { Sister (aged } 39 \text { years) } \\
\text { Great niece (aged } 5 \text { years) } \\
\text { Nephew (aged } 18 \text { years) }\end{array}$ & $\begin{array}{l}\text { Nil } \\
\text { Unsteady gait } \\
\text { Nil }\end{array}$ & $\begin{array}{l}\text { Minimal wasting of thighs } \\
\text { Nil } \\
\text { Nil }\end{array}$ & $\begin{array}{l}52 \\
24(70) \ddagger \\
37\end{array}$ & $\underline{ \pm}$ & $\underline{ \pm}$ & $\underline{ \pm}$ \\
\hline
\end{tabular}

* Normal limits 0-60.

Attributable to mild cerebral diplegia and not myopathy.

† Figure in parentheses indicates value before referral for biopsy.

eaten" fibres in sections stained for oxidative enzymes. Occasional motor end plates showed ultraterminal sprouting and accumulation of fibrils in axonic expansions. The changes varied from subject to subject and were non-specific although recognizably myopathic. They will be reported in greater detail later.

Positive evidence of myopathy on histopathological examination of muscle tissue correlated well with abnormal muscle contracture induced by halothane or halothane/suxamethonium. But it is important to note that in one subject (Case 5) there was both histological evidence of myopathy and muscle contracture with halothane, yet the SCPK activity was within the normal limits for our laboratory.

The pharmacological studies showed abnormal muscle activity (muscle contracture) with halothane alone in four subjects. Both halothane and suxamethonium were necessary to induce contracture in one subject; suxamethonium alone was not effective. A typical trace showing halothane-induced muscle contracture is shown in the Illustration. In control experiments with human muscle from subjects with no family history of malignant hyperpyrexia halothane-induced muscle contracture never occurred.

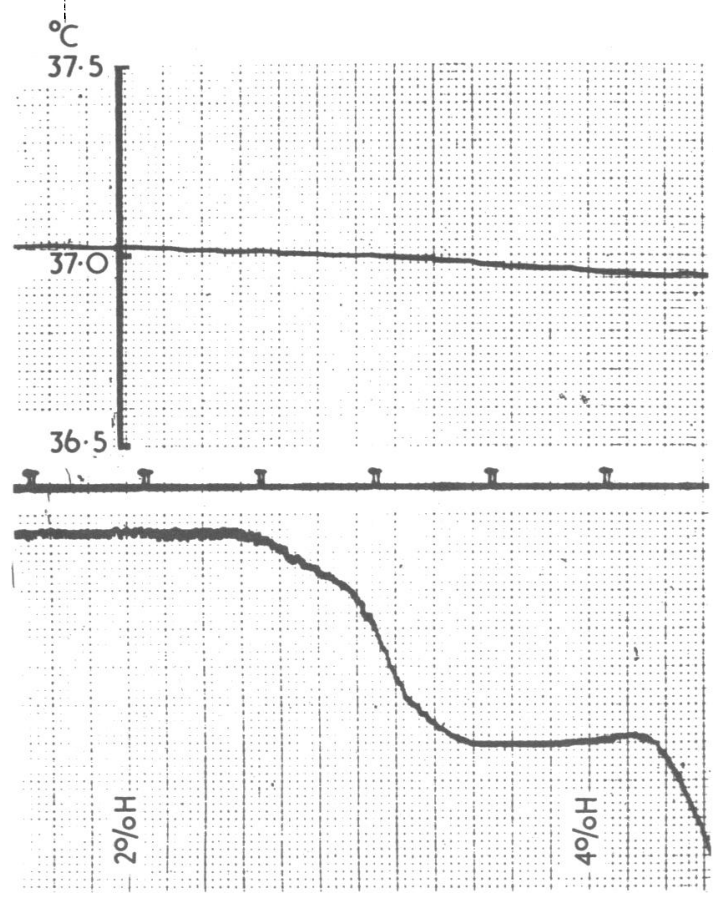

Lower trace shows muscle contractures induced by halothane $2 \% \nabla / v$ and $4 \% \mathrm{v} / \mathrm{v}$. Upper trace shows tissue-bath temperature (centigrade). Time marker (middle trace) indicates minutes.

\section{Discussion}

It is possible to provide suitable anaesthesia for the patient liable to develop malignant hyperpyrexia. A specific screen- ing test for the relatives of a patient who has developed malignant hyperpyrexia is, however, required urgently.

A striking feature of the present investigation is the fact that none of the positive reactors admitted to any symptoms attributable to myopathy. This contrasts with the severe and progressive myopathy reported by Steers et al. (1970) in the relatives of a patient who had developed malignant hyperpyrexia, though in most cases reported subsequently the myopathy has been subclinical (King et al., 1972).

Over the past three years one of us (F.R.E.) has anaesthetized over 70 myopathic patients for diagnostic muscle biopsy. All these patients received halothane and nitrous oxide but not muscle relaxants. No patient developed malignant hyperpyrexia during anaesthesia, which lasted between 60 and 90 minutes.

How are susceptible patients to be detected? The positive clinical signs are such that it is doubtful whether a busy anaesthetist would either detect them or be able to interpret them. The value of the resting SCPK activity depends on several factors. The specimen of blood should be taken without inducing ischaemia of the limb with stagnation of blood. The patient should have rested for about one hour and should have avoided vigorous muscular activity for 48 hours previously. By taking these precautions the normal limits for SCPK can be minimized (further discussed by Parikh and Thomson, 1972). One subject (Case 5) had an SCPK level within the normal range of our laboratory (0-60 IU/1), but a similar result obtained elsewhere was reported to be abnormally high, the normal limits for that laboratory being 0-30 IU/1 for adult females. We are aware that the so-called "normal limits" vary greatly in different laboratories and we feel that the value of SCPK as a screening test is significantly reduced in consequence. Conversely if too much emphasis is placed on the result of SCPK estimation false positive results will occur even with families with malignant hyperpyrexia, and this is illustrated in Case 6 , in which there was a raised SCPK level apparently related to cerebral diplegia.

The relevance of muscle contracture in malignant hyperpyrexia is not yet clear. Britt and Kalow (1970) stated that $70 \%$ of patients developing this condition have muscle contracture clinically. It is significant that in all the cases of malignant hyperpyrexia relevant to the present study muscle contracture had developed.

It may be that different forms of the disease can be identified. Muscle specimens from four subjects in the present studies developed halothane-induced contracture, whereas the muscle of a fifth (Case 3) developed contracture only when halothane and suxamethonium were combined. We have not yet had an opportunity to investigate a relative of a patient who developed malignant hyperpyrexia without muscle contracture. Nevertheless, for the present subjects the development of contracture in muscle specimens in vitro on contact with halothane, alone or combined with suxamethonium, represents a specific and abnormal response to these drugs which we believe is related to the liability to develop malignant hyperpyrexia under anaesthesia. 
N.P.K. is an M.R.C. research assistant. D.G.F.H. is in receipt of grants from the Muscular Dystrophy Group of Great Britain and also from the M.R.C. F.R.E. has received financial support from I.C.I. (Pharmaceuticals) Ltd. D.G.F.H and F.R.E have received financial support from the board of governors of Leeds General Infirmary.

\section{References}

Britt, B. A., and Kalow, W. (1970). Canadian Anaesthetists' Society fournal 17, 293.
Denborough, M. A., Forster, J. F. A., Lovell, R. R. H., Maplestone, P. A. and Villers, J. D. (1962). British fournal of Anaesthesia, 34, 395 Ellis, F. R., Harriman, D. G. F., Keaney, N. P., Kyei-Mensah, K., and Tyrrell, J. H. (1971). British fournal of Anaesthesia, 43, 721.

Griffiths, P. D. (1966). Clinica Chimica Acta, 13, 413.

Harriman, D. G. F. (1961). In Electrodiagnosis and Electromyography, ed. S. Licht, p. 134. New Haven, Connecticut, Burns and MacEachern. Isaacs, H., and Barlow, M. B. (1970). British Medical fournal, 1, 275.

Keaney, N. P., and Ellis, F. R. (1971). British Medical fournal, 4, 49.

King, J. O., Denborough, M. A., and Zapf, P. W. (1972). Lancet, 1, 365.

Larard, D. G., Rice, C. P., Robinson, R., Spencer, R. W., and Westhead R. A. (1972). British fournal of Angesthesia, 44, 93 .

Parikh, R. K., and Thomson, W. H. S. (1972). British fournal of Anaesthesia In press.

Steers, A. J. W., Tallack, J. A., and Thompson, D. E. A. (1970). British Medical fournal, 2, 341 .

\section{Circadian Periodicity of Serum Prolactin Concentration in Man}

\section{J. NOKIN, M. VEKEMANS, M. L'HERMITE， C. ROBYN}

British Medical fournal, 1972, 3, 561-562

\section{Summary}

Immunoreactive human serum prolactin of pituitary origin has been measured by a radioimmunoassay developed for ovine prolactin. Blood samples were collected at four-hour intervals during a 24-hour period from 12 non-pregnant women, three pregnant women, and seven adult men. A circadian periodicity was found in serum prolactin concentration, with peak values during the night, between 1 a.m. and 5 a.m. for the nonpregnant women, and at $5 \mathrm{a.m}$. for the adult men. Mean serum levels of prolactin were 1.5 times higher in nonpregnant women than in men. In women investigated during the last month of their pregnancy the mean serum prolactin levels were 2.3 times higher than in the non-pregnant women, but there was no circadian periodicity.

\section{Introduction}

A circadian periodicity in serum prolactin concentration has been found in rats (Clark and Baker, 1964; Dunn et al., 1972). The purpose of the present study was to investigate whether a similar rhythm exists in man.

\section{Subjects and Methods}

Blood samples were collected at four-hour intervals during 24 hours from 22 normal adult volunteers-12 non-pregnant women aged 19-44 years, 7 men aged 23-64 years, and 3 pregnant women aged 27-33 years who were investigated during the last month of their pregnancy. Among the non-pregnant women two were in the follicular phase and 10 were in the luteal phase of their menstrual cycle.

Human prolactin was measured in serum using a radioimmunoassay method initially developed for ovine prolactin (Davis et al., 1971) and extended to human prolactin (L'Hermite et al., 1972a; Midgley et al., 1972). Highly purified ovine prolactin (LER-860-2) was labelled with ${ }^{125}$ I (Radiochemical Centre, Amersham, England) at a dose of $1 \mathrm{mCi} / 2.5 \mu \mathrm{g}$, using

Human Reproduction Research Unit, Hôpital Saint Pierre, University of Brussels, Belgium

J. NOKIN, M.D., Postdoctoral Fellow

M. VEKEMANS, M.D., Resident

M. L'HERMITE, M.D., Resident

C. ROBYN, M.D., Research Worker, Fonds National de la Recherche Scientifique the chloramine-T method (Greenwood et al., 1963). The labelled prolactin was separated from free iodide by chromatography on Sephadex G-100 (Pharmacia, Uppsala, Sweden) equilibrated with $0.05 \mathrm{M}$ phosphate buffer at $\mathrm{pH} 7 \cdot 0$. Thereafter the fractions of the ${ }^{125}$ I-prolactin peak were diluted with phosphate buffer in saline containing $1 \%$ egg white (Sigma Chemical Co., St. Louis, Mo.) in order to obtain a working solution containing 50,000 c.p.m./100 $\mu$ l. The assays were conducted according to the double antibody method using $200 \mu \mathrm{l}$ of sample or standard with $200 \mu \mathrm{l}$ of antiovine prolactin serum 770 at a dilution of $1: 72,000$ in normal rabbit serum diluted at 1:600 in phospliate-buffered saline (pH 7.0) containing $0.05 \mathrm{M}$ ethylenediaminetetra-acetic acid (EDTA), $300 \mu$ of phosphate buffer in saline containing $1 \%$ egg white, $100 \mu \mathrm{l}$ of radioactive tracer solution, and $200 \mu \mathrm{l}$ of sheep antirabbit immunoglobulins serum at a dilution of $1: 100$ in phosphate-buffered saline containing 0.05 M EDTA.

Non-equilibrium conditions were employed as described previously (L'Hermite and Midgley, 1971). No cross-reaction was detected in this system with human growth hormone and with human chorionic somatomammotrophin (L'Hermite et al.s 1972b; Midgley et al., 1972). All assays were conducted with reference to pooled sera collected from pregnant women. We conferred an immunological activity of $1.0 \mathrm{mU}$ on the amount of prolactin contained in $1.0 \mu \mathrm{l}$ of this pool used as laboratory standard. All samples from the same subject were run in triplicate in the same assay. The assay results were calculated according to the recommendations of Rodbard et al. (1968).

\section{Results}

The mean serum prolactin levels observed over the 24-hour period are shown in the Chart for men and non-pregnant women, and in the Table for pregnant women. The data were submitted to a variance analysis (Snedecor, 1956) of the between-subjects variation and the within-subject variation due to the influence of time. There was a highly significant variation between the subjects in serum levels of prolactin-non-pregnant women $\mathrm{F}=8.27, \mathrm{P}<0.001$; adult men $\mathrm{F}=3.81, \mathrm{P}<0.001$; pregnant women $F=8.09, P<0.01$. In addition in the non-pregnant women the levels of prolactin were higher $(F=68.99$; $P$ $<0.001$ ) at 1 a.m. (mean $500 \mathrm{mU} / \mathrm{ml}$ ) and 5 a.m. $(504 \mathrm{mU} / \mathrm{ml}$ ) than at 9 a.m. (332 and $312 \mathrm{mU} / \mathrm{ml})$, 1 p.m. $(273 \mathrm{mU} / \mathrm{ml}), 5$ p.m. $(299 \mathrm{mU} / \mathrm{ml})$, and 9 p.m. (331 mU/ml). There was no significant difference in serum levels of prolactin found at 9 a.m. between the first and the second day $(F=0.24 ; P>0.05)$. The prolactin levels started to increase at 9 p.m., but this rise was not significant $(F=1.76 ; P>0.05)$ compared with the values seen at 1 p.m. and 5 p.m.

In the men there was also a peak in serum prolactin levels 